\title{
Archaeometallurgical Investigation of Iron Artifacts from Shipwrecks - A Review
}

\author{
D. Ashkenazi1 ${ }^{,}$, , E. Mentovich ${ }^{2}$, D. Cvikel 3,5 , \\ O. Barkai ${ }^{4}$, A. Aronson ${ }^{1}$ and Y. Kahanov ${ }^{3}$ \\ ${ }^{1}$ Faculty of Engineering, Tel Aviv University, Ramat Aviv \\ ${ }^{2}$ School of Chemistry, Tel Aviv University, Ramat Aviv \\ ${ }^{3}$ Leon Recanati Institute for Maritime Studies, University of Haifa, Haifa \\ ${ }^{4}$ Department of Maritime Civilizations, University of Haifa, Haifa \\ ${ }^{5}$ Centre d'Histoire des Techniques CH2ST/EA127, \\ Université Paris 1 - Panthéon-Sorbonne \\ 1,2,3,4 Israel \\ ${ }^{5}$ France
}

\section{Introduction}

This chapter reviews the archaeometallurgical investigations of ancient iron artifacts, which were retrieved from two different shipwrecks. The analysis is based on materials science and archaeological literature, as well as archaeometallurgical observations made by the authors. Various tools were used in the investigation process, such as radiography, optical microscope, SEM with EDS, XRF, OES and microhardness measurements, and the results were compared with archeological-typological analyses within the relevant historical context. The connection between microstructure and mechanical properties enables the materials scientist to surmise the use of processes such as hammering, heating and quenching in ancient times. Such information regarding the iron artifacts may assist the archaeologist in understanding ancient manufacture processes, and what the probable uses of the objects were, as well as dating the objects and finding their ore origin. This information may also assist in the conservation process of these objects.

\section{Archaeometallurgical background of ancient iron objects}

Studies of ancient metals exist in the literature (e.g., Wadsworth \& Lesuer, 2000; Pense et al., 2000; Blyth et al., 2002; Perttula, 2004; Nicodemi et al., 2005; Hošek \& Košta, 2006; Mapelli et al., 2007; Barrena et al., 2008; Caporaso et al., 2008). However, it is rare to find a general review which relates to the archaeometallurgical methods and includes an interpretation of the microstructure. It is even more challenging to find a metallurgical review relating to iron objects retrieved from a marine environment. The present paper attempts to fill this gap and provide information regarding the techniques of archaeometallurgy as they are applied to

* Corresponding Author 
archaeological objects made of iron and retrieved from shipwrecks discovered in the Mediterranean Sea.

Information regarding ancient iron objects, including composition, trace elements and microstructure, as well as their manufacturing processes, can provide essential data concerning their date, their probable use, their origin and the technology of the time (e.g., Mentovich et al., 2010; Ashkenazi et al., 2011; Eliyahu et al., 2011). Intercultural interactions such as wars or trade connections can also be examined through this data. This information can also assist in improving the objects' conservation process. From the materials science and engineering point of view, it is interesting to explore the ways in which metals have been employed in the manufacturing process of metallic objects in ancient civilizations. Combining the empirical experiments of materials and the theoretical models allows an appreciation for the effects of structure on the material's properties. The relation between microstructure and mechanical properties enables the manipulation and control of the properties of metals by processes such as casting, cold working, hot working, heating and quenching. These technological aspects are strengthened and become more intriguing after the reaction of the iron with the seabed environment.

\subsection{Wrought iron, cast-iron and steel}

In the classification of ferrous alloys, pure iron $(\mathrm{Fe})$ is defined as iron containing less than 0.008 by weight ( $\mathrm{wt} \%$ ) carbon (C). At room temperature, pure iron is composed of a ferrite phase, which is an $\alpha$ iron body-centered cubic (BCC) unit cell. At higher temperatures $\left(912^{\circ} \mathrm{C}\right)$, the ferrite phase transforms into austenite $\gamma$ iron, with face-centered cubic (FCC) unit cell. For rather pure iron manufacturing, a reduction process should be applied at a temperature of around $1200^{\circ} \mathrm{C}$ (viscous slag with solid-state phase), turning the iron ore into a spongy matter called bloom (Tylecote, 1962). The bloom contains many inclusions, known as slag. In order to reduce the amount of slag in the metallic iron bulk, the bloom is then hammered. The result is a heterogeneous, ductile, malleable, and easily welded material named 'wrought iron', with an average amount of $0.1 \mathrm{wt} \%$ C (Tylecote \& Black, 1980). The term 'wrought iron' literally means 'worked iron'. In order to join two pieces of iron together, a forge-welding process is carried out at temperatures below that of melting $\left(1538^{\circ} \mathrm{C}\right.$ for pure iron) and above half of it, resulting in an austenite ductile phase, which allows for intensive dislocation movement (Murray, 1993; Barrena et al., 2008).

Ferrous alloys such as steel and cast-iron are defined as alloys containing Fe as the prime element and $C$ as the secondary element (Callister, 2000). Iron alloys containing 0.008-2.14 $\mathrm{wt} \% \mathrm{C}$ include a combination of $\alpha$ ferrite and an intermediate compound called cementite $\left(\mathrm{Fe}_{3} \mathrm{C}\right)$, and are defined as steel. The alternating microstructure between $\alpha$ ferrite and $\mathrm{Fe}_{3} \mathrm{C}$ gives the pearlite phase optimized mechanical properties. The massive amount of cementite results in good hardness and abrasion resistance, but also in higher brittleness (Goodway, 1996).

Outstanding crystalline microstructure is formed when steels are cooled from extremely high temperatures at a critical cooling rate. This kind of microstructure, named Widmanstätten (or Thomson structure) was discovered by the geologists A. von Widmanstätten and C. von Schreibers in 1808, after they etched various meteorites, and revealed different morphologies (Vander Voort, 2004). Widmanstätten structure pattern 
(Fig. 1) is a very common iron meteoritic structure (Szurgot et al., 2008). Widmanstätten microstructure of proeutectoid ferrite is observed only over a limited range of transformation temperatures and C contents (Vander Voort, 2004). The main factors affecting the formation of Widmanstätten structure in steels are the chemical composition of the steel, the cooling rate and the size of austenite grains (Aliya \& Lampman, 2004; Todorov \& Khristov, 2004). Low C steels, which contain less than $0.3 \mathrm{wt} \% \mathrm{C}$, have a tendency to form a Widmanstätten pattern, when they have a coarse austenitic grain, and have been rapidly cooled from austenitic phase (Todorov \& Khristov, 2004).

Archaeological iron can be classified into two different categories: wrought iron and castiron. The use of cast-iron as a significant structural material, and its mass production, began in England (at Coalbrookdale) during the eighteenth century, when A. Darby devised a new method of smelting iron with coal (Goodway, 1998). The properties of cast-iron can be controlled by adding various alloying elements to it.

Commercial cast-iron is defined as a ferrous alloy containing between 2.14 and $4.5 \mathrm{wt} \% \mathrm{C}$, and it usually contains between 0.5 and $3 \mathrm{wt} \%$ silicon (Si) and smaller amounts of other elements as phosphorus (P), sulphur (S) and manganese (Mn) (Stefanescu, 1996a, Mentovich et al., 2010). It has a relatively low melting point, good fluidity, good hardness and good wear resistance, but it tends to be brittle. The main difference between white and gray cast-irons is in the amount of silicon present in the alloy. While white cast-iron contains less than $1 \mathrm{wt} \% \mathrm{Si}$, gray cast-iron contains more than $1 \mathrm{wt} \% \mathrm{Si}$ (Goodway, 1998; Mentovich et al., 2010). White cast-iron is named for its white fractured surface, whereas gray cast-iron is named for its gray fractured surface, which occurs because of the presence of graphitic flakes. Both white and gray cast-iron can be identified by their fractured surface (Callister, 2000).

The slow cooling rate of solidification or the high presence of silicon (which is a graphite stabilizing element) in the cast-iron, causes a graphite formation (Menon \& McKay, 1996; Stefanescu, 1996b). Adding more than $1 \mathrm{wt} \%$ Si causes the carbon to precipitate as dark graphite flakes surrounded by a matrix of bright pearlite (alternating thin layers of $\alpha$ ferrite and dark cementite) (Callister, 2000).

The structure of steels and cast-irons may oscillate between different microstructures as a result of $\mathrm{C}$ amounts, different alloying elements, the temperature of the heat treatment, and the rate of cooling. When steel with a pearlite phase in room temperature is heated to a higher temperature $\left(912^{\circ} \mathrm{C}\right.$ ) and rapidly cooled (quenched) to room temperature, another phase is formed called martensite (metastable state). This has a body-centred tetragonal (BCT) elongated unit cell, which includes $\mathrm{C}$ atoms occupied in it. The martensite morphology depends on $\mathrm{C}$ content: below $0.6 \mathrm{wt} \% \mathrm{C}$ content, the structure consists of martensite needles; between 0.6 and $1.0 \mathrm{wt} \%$, the martensite is a mixture of needles lath and plate morphologies; and above $1.0 \mathrm{wt} \% \mathrm{C}$, the structure consists of plates with some retained austenite remains between the plates, as well as some martensite needles extending from the plates (Aliya \& Lampman, 2004). The martensite phase has high hardness but it is also a very brittle phase (Callister, 2000).

\subsection{Underwater corrosion}

When iron is exposed to an atmospheric environment it forms different iron-oxides, such as Magnetite $\left(\mathrm{Fe}_{3} \mathrm{O}_{4}\right)$, Hematite $\left(\alpha-\mathrm{Fe}_{2} \mathrm{O}_{3}\right)$ and Maghemite $\left(\gamma-\mathrm{Fe}_{2} \mathrm{O}_{3}\right)$ (Cornell \& Schwertmann, 

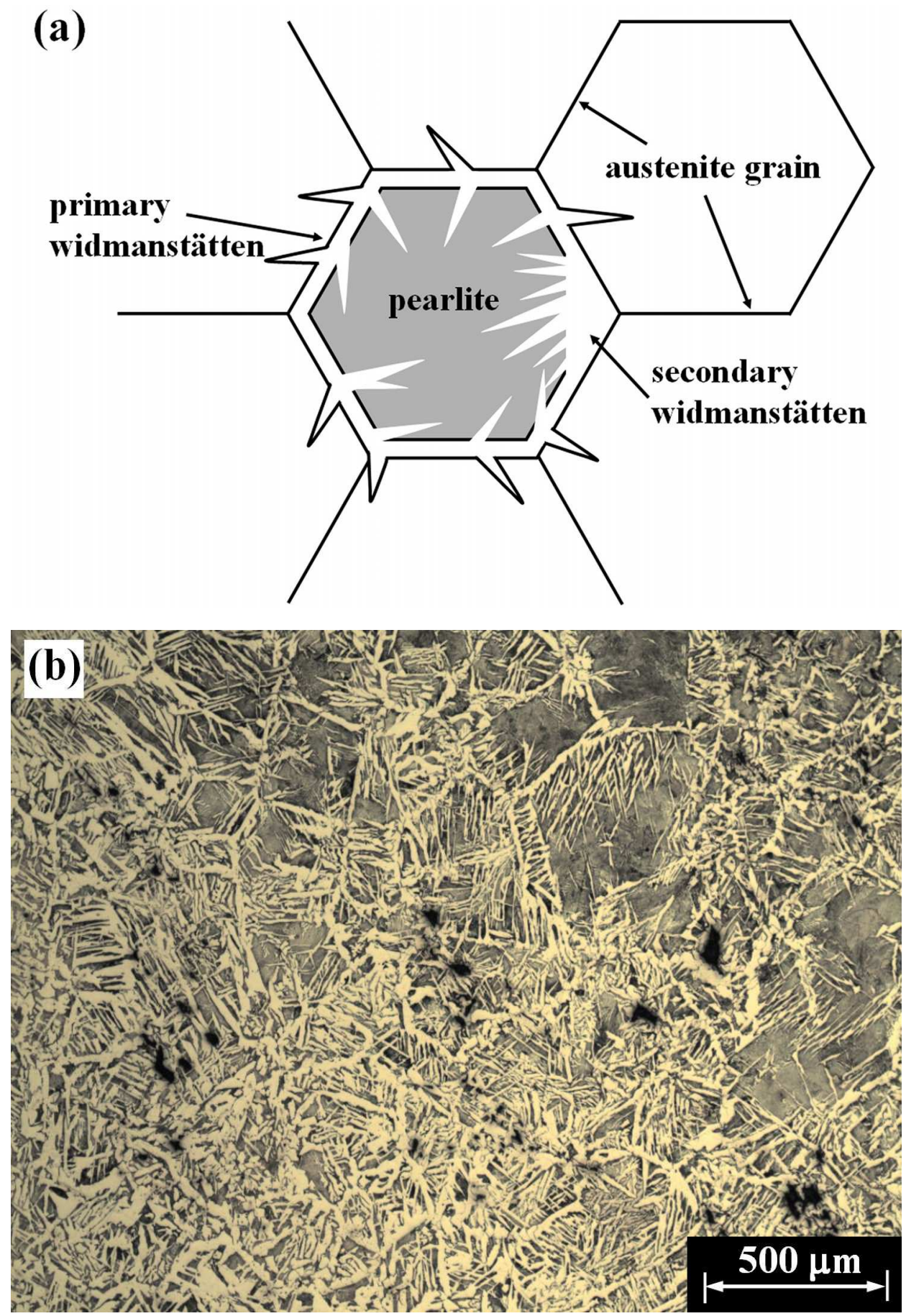


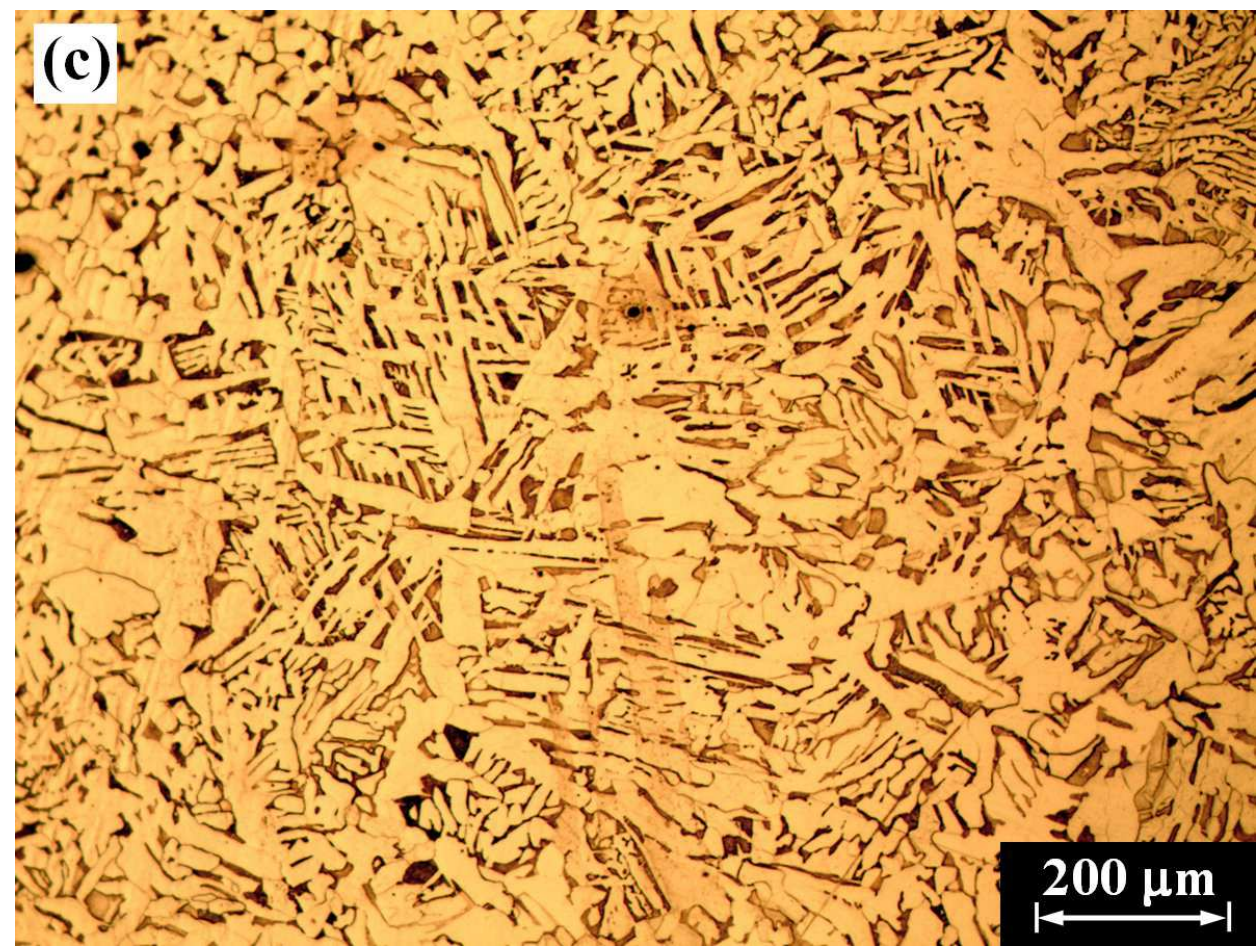

Fig. 1. Widmanstätten microstructure: (a) schematic illustration (Drawing: D. Ashkenazi), (b) OM (ZEISS, AXIO Scope A.1) metallographic image (of a T-shaped anchor) showing Widmanstätten microstructure, and (c) Widmanstätten microstructure in higher magnification OM (Photos: A. Aronson).

2003). At temperatures higher than $560^{\circ} \mathrm{C}$, the common order of iron-oxide layers (from the internal to the surface respectively) is $\mathrm{Fe} / \mathrm{FeO} / \mathrm{F}_{3} \mathrm{O}_{4} / \mathrm{F}_{2} \mathrm{O}_{3} / \mathrm{O}_{2}$ (Fontana, 1987). Reddishorange powder rust and the presence of many cracks and cavities on the surface of the objects are indications of an ongoing active corrosion process, causing continuous loss of metal, as well as degradation of mechanical properties (Selwyn, 2004).

Ancient objects made of iron, which were excavated from a marine environment (e.g., shipwrecks) after being buried for centuries under layers of sand of various types and thickness usually suffer from severe corrosion, and are generally covered with a thick encrustation coating and concretion, similar to what happened to the copper nails of the Ma'agan Mikhael shipwreck (Kahanov et al., 1999). The nails excavated from the Ma'agan Mikhael shipwreck had black colored concretions, which were assumed to be iron, but were identified later as unalloyed copper. The concretion was composed of a black-blue mineral called covellite (CuS) matrix. The concretion also included quartz particles (sand), and shell (calcium carbonate) inclusions (Kahanov et al., 1999). Copper in aerobic underwater surroundings tends to oxidize quite rapidly, resulting in a toxic protective layer that protects the copper from sulphides resulting from a reaction with microorganisms. Therefore 
sulphidization of the copper nails occurred only inside the wood, in a rich bacterial environment which probably accelerated the concrete formation (Kahanov et al., 1997; Kahanov et al., 1999).

Therefore, for successful study and conservation of these items, it is important to understand the corrosion and concretion mechanisms of submerged iron artifacts. Corrosion of archaeological iron artifacts buried under sand in seawater is an electrochemical process, which involves anodic and cathodic reactions in an aqueous electrolytic environment and a biological process as well, involving anaerobic bacteria (North, 1976). When iron is buried in aqueous solution, the oxide layers grow slowly, resulting in oxide compounds such as: Goethite $(\alpha-\mathrm{FeOOH}), \quad$ Akaganeite $(\beta-\mathrm{FeOOH})$, and Lepidocrocite $(\gamma-\mathrm{FeOOH})$ (Balasubramaniam, 2003; Cornell \& Schwertmann, 2003; Neff et al. 2004; Neff et al. 2005; Neff et al. 2006a; Neff et al., 2006b; Balos et al., 2008; Barrena et al., 2008; Park et al., 2010). During the underwater concretion the metallic iron slowly dissolves and then the metallic surface is covered with a ceramic, aggregate coating. This concretion, which covers the iron artifact, forms a protective 'cocoon' in the sea. Concretion formation occurs as a result of interaction between iron and its surrounding environment. In this process, which is one of the most fascinating features of iron corrosion, the metal's surface decreases, whereas the concretion conglomerate increases.

Since iron is a non-toxic metal, it can be colonized in the underwater marine environment, which includes sand, shells particles and marine organisms, and these create a calcium carbonate $\left(\mathrm{CaCO}_{3}\right)$ shell (North, 1976). Sometimes the catalyst for this process is bacterial organisms, which are present in wooden ships and consume/degrade the cellulose of the waterlogged wood (Kahanov, 1997).

Removal of the concretion layer or cleaning the corrosion is required in order to learn about the artifacts, but this procedure might damage the metal object, if anything remains. In such cases it is recommended to examine the object with a non-destructive method, such as X-ray radiography, before the de-concretion process begins. Sometimes, information about an object can be obtained from the radiography itself (Pulak, 2004).

After retrieving the objects from the sea and beginning the de-concretion/corrosion process, wrought iron and cast-iron tend to corrode in dissimilar ways. Wrought iron corrodes along the slag inclusions, and the presence of chlorides in the alloy accelerates the corrosion rate (Balasubramaniam et al., 2003). Orange-brown drops, known as 'sweating', are formed on the surface of the iron object, indicating the presence of chlorides (Selwyn, 2004). Cast-iron exposed to the atmospheric environment can be corroded by graphitization, with accelerated corrosion on the external surface of the object (which is rich in graphite) and at the boundaries between the graphite and the metal (Najjaran et al., 2006).

\section{Studying cases of iron artifacts from shipwrecks for a better understanding of ancient cultures}

The present paper describes two case studies related to iron objects recovered during underwater excavations in Israel. The earlier case is the archaeometallurgical study of two iron anchors retrieved from the seventh-eighth century Tantura F shipwreck (Eliyahu et al., 2011), and the second is the archaeometallurgical study of two cast-iron cannonballs retrieved from the nineteenth century Akko 1 shipwreck (Mentovich et al., 2010). 
Archaeometallurgy studies were used to provide essential information regarding dating, processing, and manufacturing techniques of the objects. In both cases, the artifacts were found covered with corrosion, encrustation and a concretion layer (Fig. 2 and Fig. 8). The samples were cut, roughly polished, and mounted in Bakelite at 180 psi pressure and a temperature of $180^{\circ} \mathrm{C}$. Surface preparation included grinding the samples with silicon carbide papers, grades 240-600 grit, followed by polishing with 5 to 0.05 micron alumina pastes. Finally the samples were polished with 0.05 micron colloidal silica polishing suspension paste, and etched using Nital acid (Mentovich et al., 2010; Eliyahu, et al., 2011).

\subsection{Case Study I: T-shaped iron anchors from the Tantura F shipwreck}

The Tantura F shipwreck was discovered in Dor lagoon, Israel in 1995. It was excavated during five seasons in 2004-2008. Combining ${ }^{14} \mathrm{C}$ dating with typological study of the pottery, the shipwreck was dated to between the second half of the seventh and the end of the eighth centuries AD (Barkai \& Kahanov, 2007; Barkai et al., 2010). Among the finds exposed in the Tantura F shipwreck were two T-shaped type iron anchors: one on the starboard side and the other on the port side, close to the bow (Fig. 2). Both anchors were found broken, with part of the shank and the anchor cable ring missing. Anchor A was found under the wooden hull, touching it (Fig. 2a), while Anchor B was found concreted to the outside of the planking below the hull (Fig. 2b).
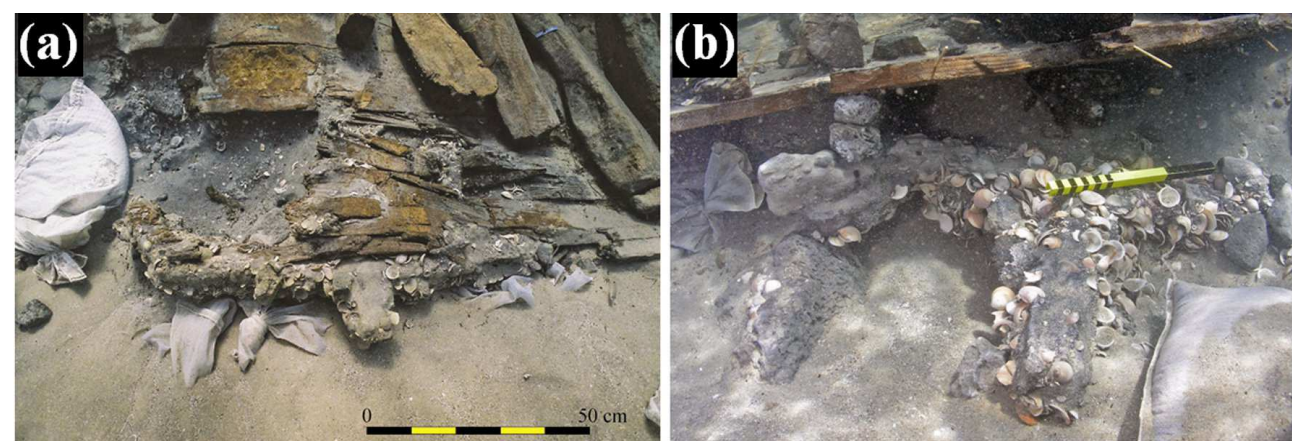

Fig. 2. The Tantura F anchors covered with a thick encrustation coating and concretion: (a) Anchor A and (b) Anchor B attached to the vessel (Photos: I. Grinberg).

Both anchors (Fig. 3) were considered to be found in-situ, thus dating them to the time of the shipwreck. The two anchors were retrieved from the seabed covered by a $4 \mathrm{~cm}$ thick gray layer of encrustation coating and concretion composed of sea sand, shells and small stones; however, the core of the iron shank and the arms were of solid, shining and hard iron.

The examination of the T-shaped anchors included radiography, metallographic crosssections (Fig. 4), Optical Microscope (OM), Vickers microhardness tests, Scanning Electron Microscope (SEM) with energy dispersive spectroscopy (EDS) analysis, and Optical Emission Spectroscopy (OES) analysis (Eliyahu et al., 2011). For the metallographic sampling three cross-sections were cut from two different parts of Anchors A and B for according to ASTM E3-01 standard. 

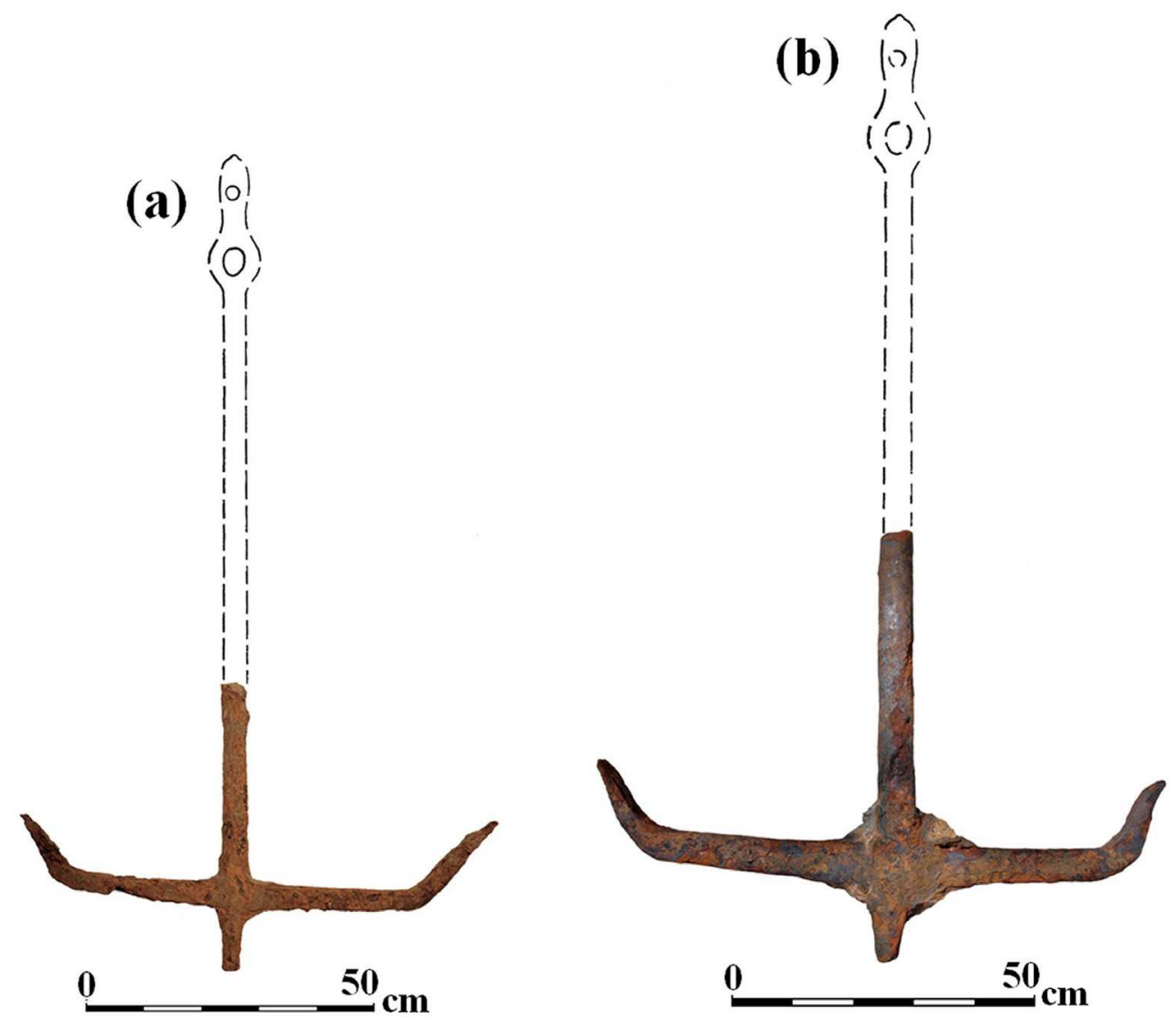

Fig. 3. Images of the Tantura F T-shaped iron anchors: (a) Anchor A and (b) Anchor B (Photo: J.J. Gottlieb, Drawing: O. Barkai).

The study revealed the microstructure and manufacturing process of the two T-shaped iron anchors (Eliyahu et al., 2011). A microscopic image of the concretion coating of Anchors A is shown, revealing the corrosion layer and sand particles (Fig. 5). A heterogeneous microstructure was observed at the core of the iron Anchors, containing ferrite, pearlite and Widmanstätten ferrite-pearlite (Fig. 6). This kind of microstructure is typical of wrought iron which has been made by bloomery. Slag inclusions were observed in both anchors, with a typical morphology of wüstite $(\mathrm{FeO})$ trapped in a glassy matrix. Typical OM image of slag inclusions that were trapped in anchor A are shown in Fig. 7.

Vickers microhardness (Future-Tech Model FM-700e tester) measurements, with a load of 100 g-force, revealed decarburization, probably due to the final hot-working process. A decarburization profile was achieved for both anchors along the diameter of the shanks cross-section (Eliyahu et al., 2011). Chemical etching followed by soda-blast cleaning revealed some forge-welding lines, hinting at the manufacturing process of the two anchors (Eliyahu et al., 2011). 

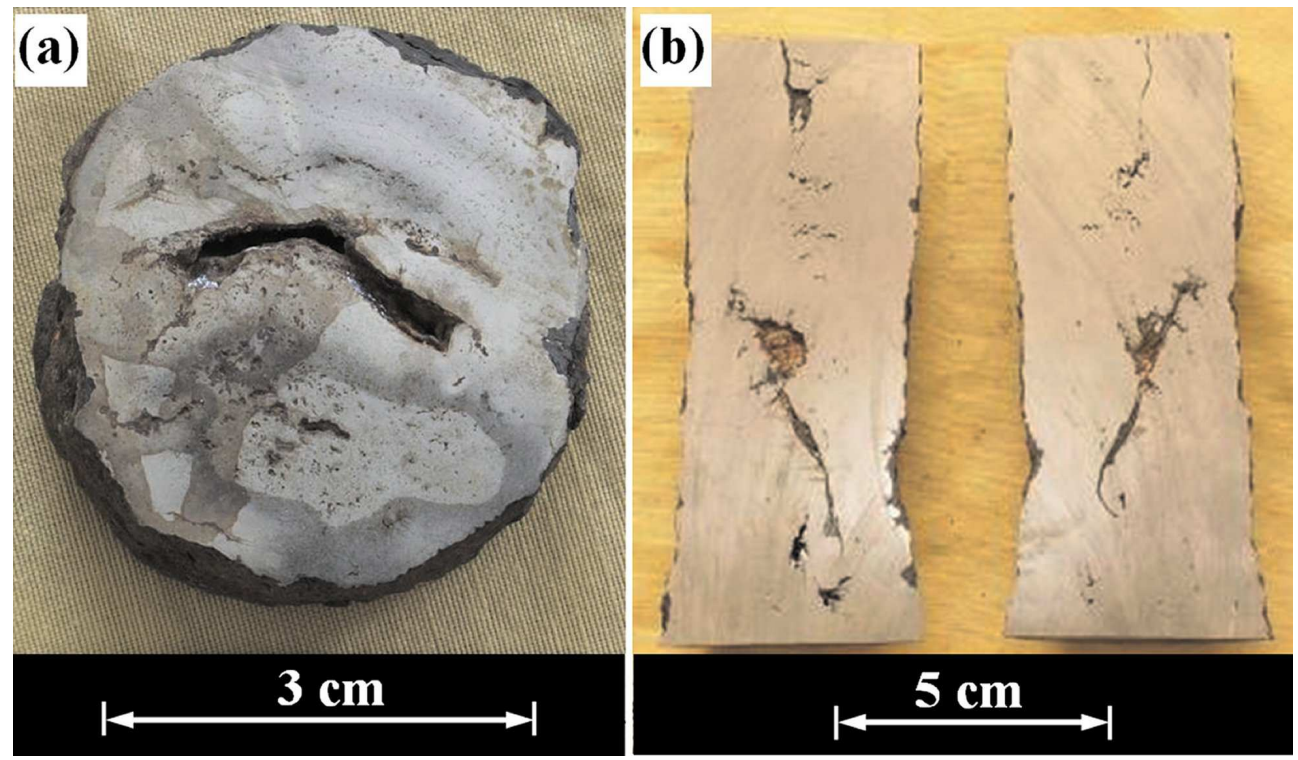

Fig. 4. The metallographic sections of the Tantura F Anchor A at the (a) transverse crosssection after polishing and etching, and (b) longitudinal cross-section before polishing and etching (Photos: A. Aronson).

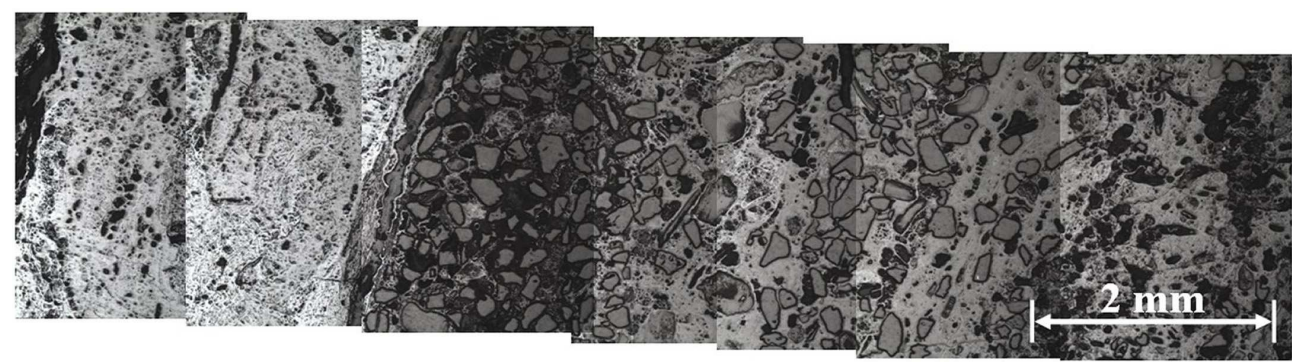

Fig. 5. Metallographic section of the Tantura F Anchor A corrosion layer (left) and the encrustation coating that includes sand particles (center and right) (Photos: D. Ashkenazi).

\subsection{Case Study II: Cast-iron cannonballs from the Akko 1 shipwreck}

The Akko 1 shipwreck was a Mediterranean naval auxiliary brig discovered in Akko harbour, and excavated during three seasons between 2006 and 2008. Various artifacts were discovered in the shipwreck, among them small-arms and ammunition, suggesting its involvement in a naval battle (Cvikel \& Kahanov, 2009). Three cannonballs, which were identified as 9-,12-, and 24-pdrs, were retrieved from the Akko 1 shipwreck. Theoretically, any of them could have been a shot that hit the ship (Cvikel \& Kahanov, 2009: 51; Mentovich et al., 2010). The cannonballs were found covered with a thick layer of encrustation coating (Fig. 8). Two of the cannonballs (Fig. 9), the 9-pdr and the 24-pdr, were studied using archaeometallurgical methods (Mentovich et al., 2010). The 

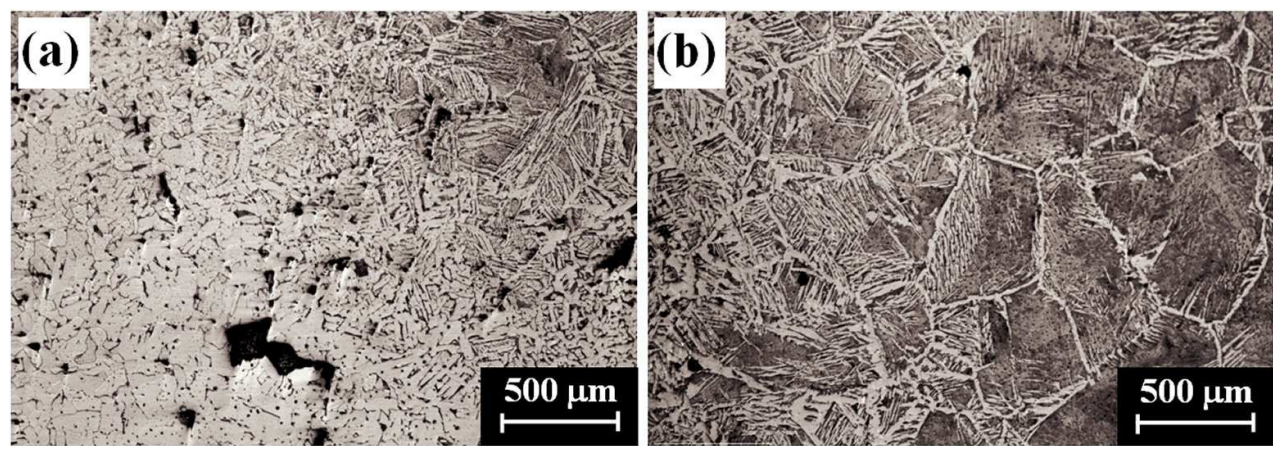

Fig. 6. OM metallographic image of the T-shaped Anchor A showing the heterogeneous structure of a 'wrought iron' (Photos: A. Aronson).
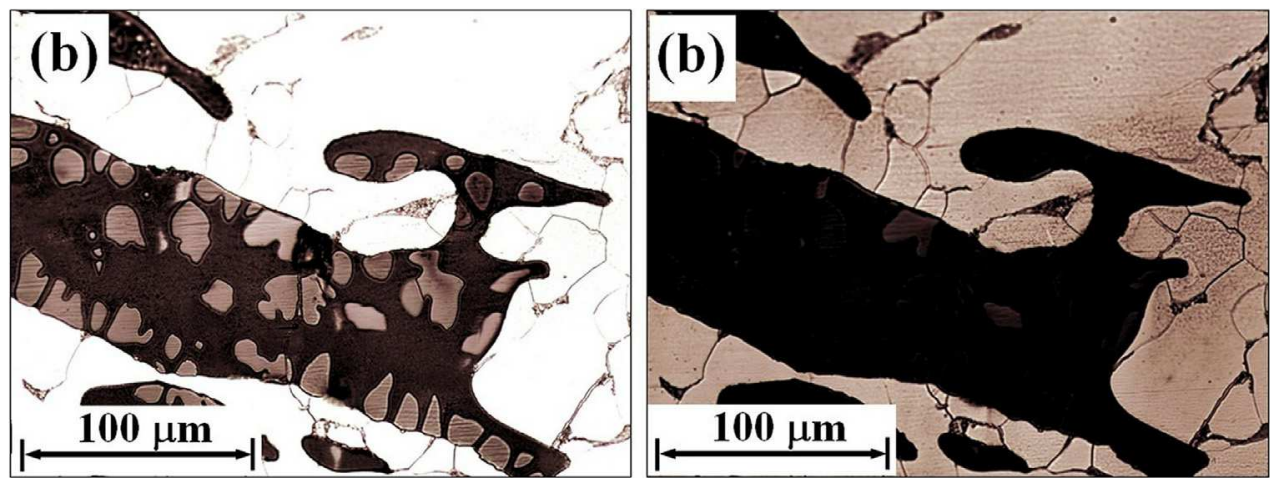

Fig. 7. OM metallographic image of (a) typical slag inclusions that were trapped in anchor A (high intensity of light), (b) $\alpha$ ferrite grains at the area which surrounds the slag inclusions (Photos: A. Aronson).
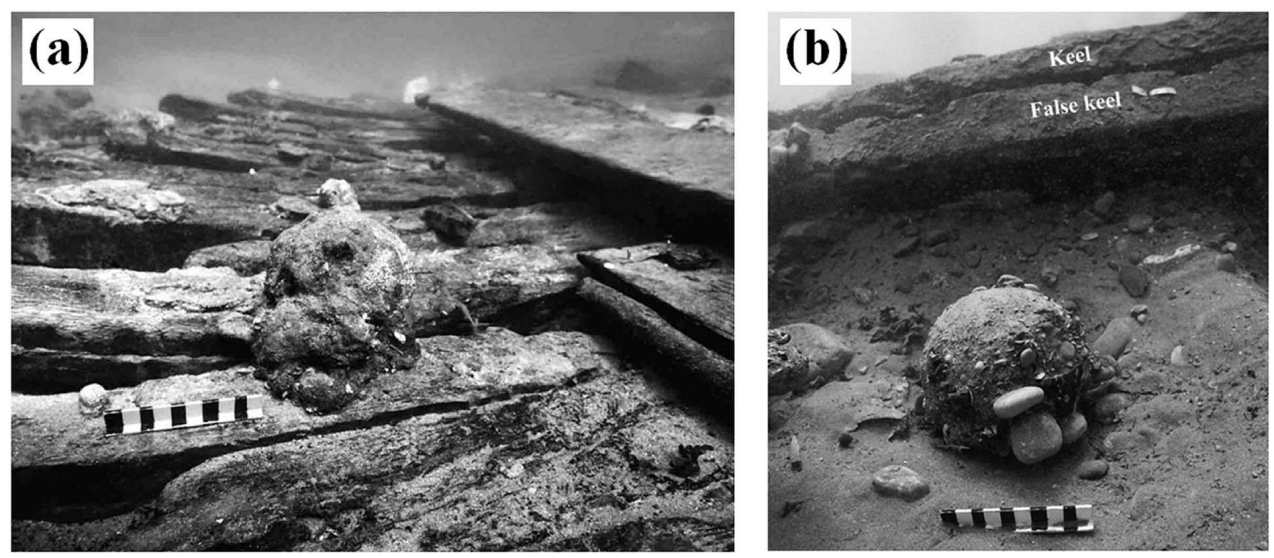

Fig. 8. Images of Akko 1 shipwreck cannonballs covered with a thick layer of encrustation coating: (a) on the framing timbers, and (b) near the false keel (Photos: S. Breitstein). 

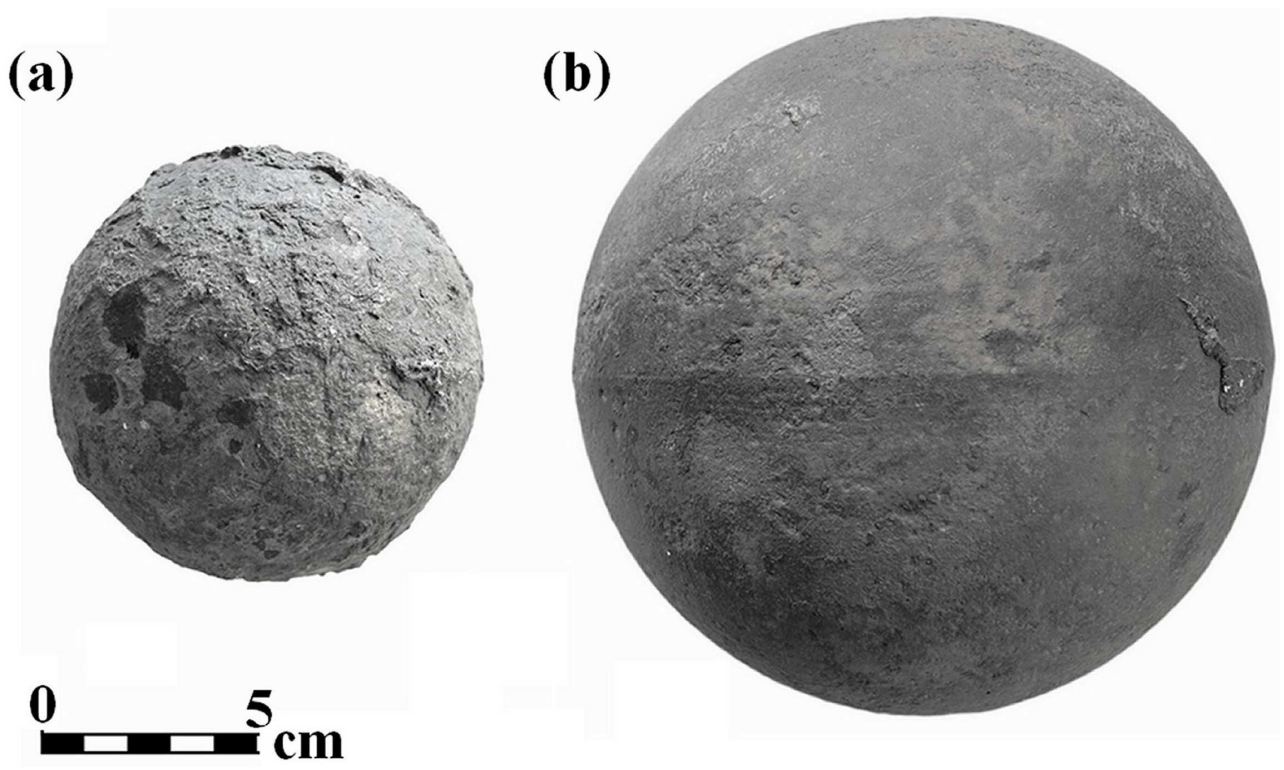

Fig. 9. Images of the Akko 1 shipwreck (a) 9-pdr and (b) 24-pdr cannonball, after removal of the concretion layer (Photo: J. J. Gottlieb).

examination of the cannonballs included OM, SEM-EDS, X-Ray Fluorescence (XRF) and Vickers microhardness tests.

The results showed that the two cannonballs were made of cast-iron and manufactured with sand casting moulds. The sand remains found within voids in both cannonballs were also studied by petrography (Mentovich et al., 2010). The OM examination of the two cannonballs revealed a corrosion layer at the surface of the cannonball, and a dendritic castiron microstructure beneath the surface (Fig. 10a and Fig. 11a). The 9-pdr cannonball was uniform and included only white cast-iron (Fig. 10). The cast-iron in the 24-pdr cannonball was non-uniform (Fig. 11) and included white cast-iron in the inner part of the cannonball, whereas the external part of the cannonball was composed of gray cast-iron. The difference between the two cannonballs may suggest the use of different technologies in their manufacturing process (Mentovich et al., 2010).

A chemical analysis of the composition of the cast iron of the cannonballs, revealed more than $0.5 \mathrm{wt} \%$ of manganese (Mn) in both cannonballs (Mentovich et al., 2010). In $1839 \mathrm{~J}$. Heath wrote a patent involving the addition of manganese to cast-iron, which resulted in metal free of gas porosity and blow holes (Wiltzen \& Wayman, 1999; Wayman, 2000). Thus, it was suggested that the Akko 1 shipwreck cannonballs were manufactured around the 1840s. 

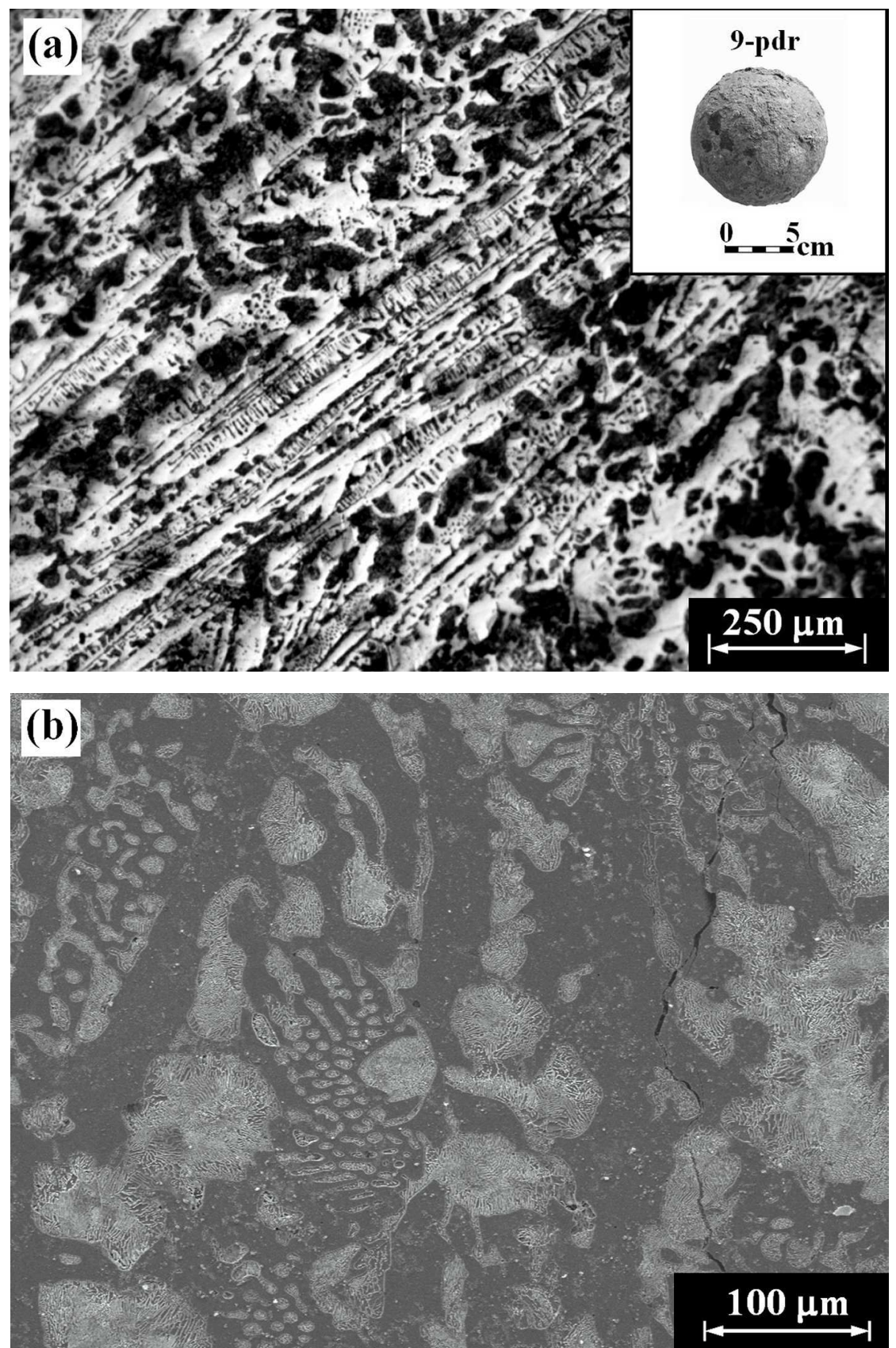

Fig. 10. The 9-pdr cannonball image of a white cast-iron as shown by (a) OM (ZEISS, AXIO Scope A.1) metallographic analysis, and (b) SEM-EDS (FEI Quanta 200FEG ESEM) analysis. (Photo: Z. Barkai / E. Mentovich / D. Schreiber). 

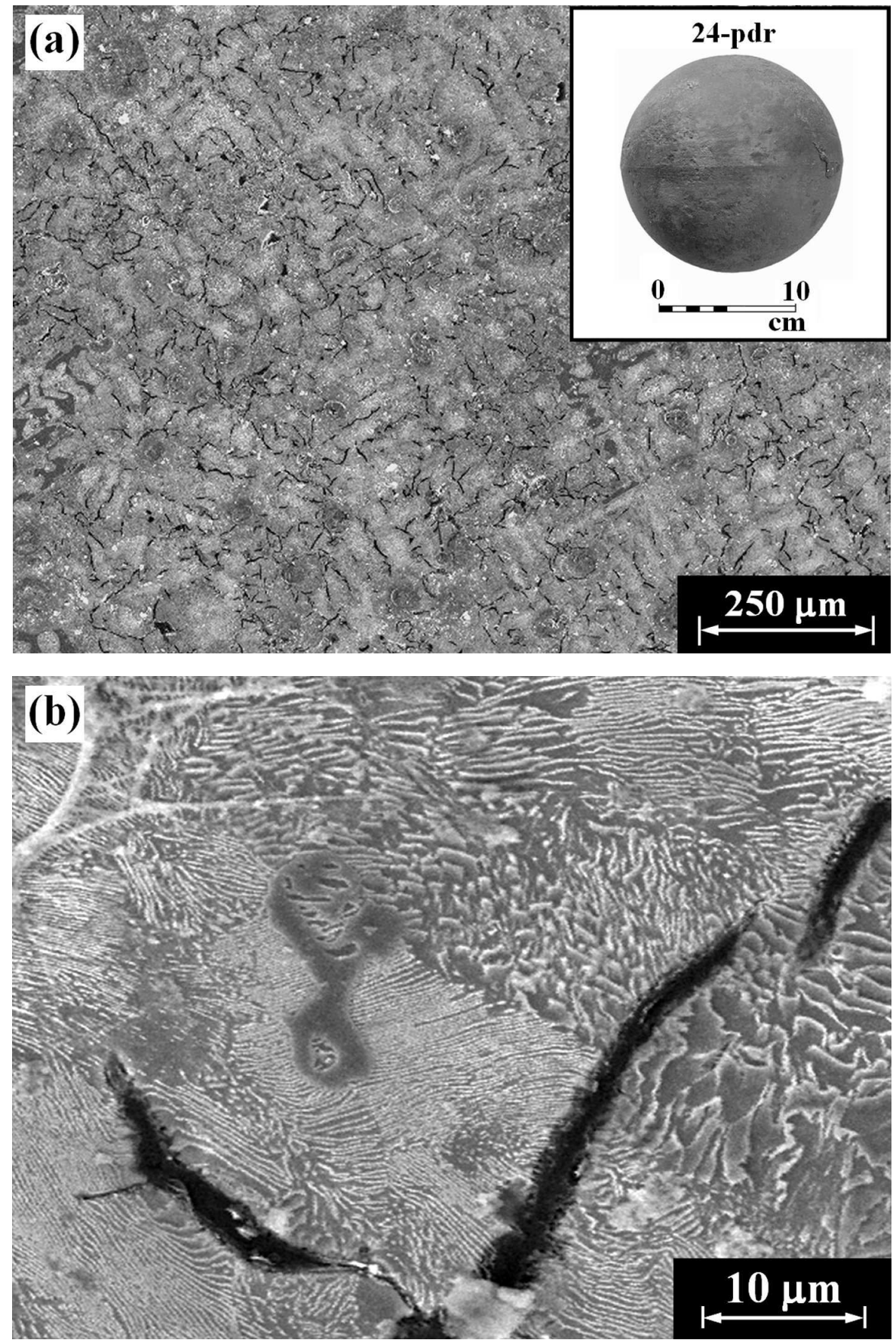


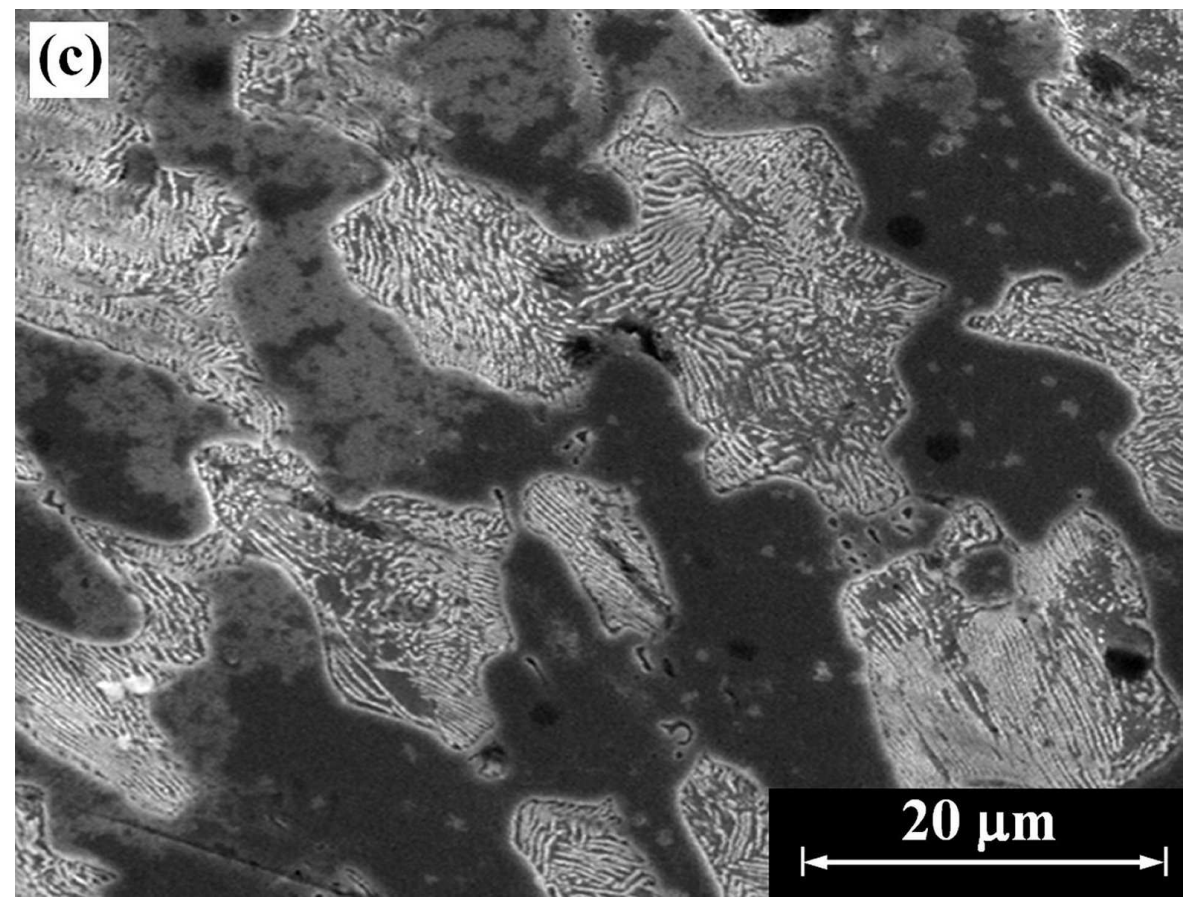

Fig. 11. The 24-pdr cannonball image of (a) a gray cast-iron as shown by an OM at the external part of the cannonball, (b) SEM-EDS analysis showing the gray cast-iron at higher magnification, and (c) a white cast-iron as shown by SEM-EDS analysis at the internal part of the cannonball (Photo: Z. Barkai / E. Mentovich / D. Ashkenazi).

\section{Discussion and conclusions}

This chapter has demonstrated a multidisciplinary study of archeology and metallurgy. It reviewed archaeometallurgical investigations of ancient iron artifacts retrieved from shipwrecks. The analyses were based on the archaeological-typological study of the finds, materials science, and archaeometallurgical observation.

It has been demonstrated here that using tools like OM, SEM-EDS, XRF and microhardness test may assist archaeologists in revealing more information regarding ancient iron objects retrieved from a marine environment, including their manufacturing process, as well as providing a strong hint for dating the objects, and hence a clue to the wrecking event.

In the study of the T-shaped iron anchors from the Tantura F shipwreck, it was concluded that decarburization had occurred (which is supported by microhardness measurements), probably as a result of the final hot-working process (Eliyahu et al., 2011). The information gathered from the archaeometllurgical investigation of the two T-shaped anchors found in the Tantura F shipwreck has enhanced understanding of metallurgical knowledge in the Eastern Mediterranean in the early Islamic period, and expands the database of anchors of that period. Specifically, this study indicated that the anchors found in the Tantura F 
shipwreck were of better quality and manufacture in comparison to other studied anchors, such as, for example, the eleventh century Serçe Limanı shipwreck (Stech \& Maddin, 2004; Van Doorninck, 2004).

The study of the two cast-iron cannonballs from the Akko 1 shipwreck revealed that the amount of $\mathrm{Mn}$ in both hinted that they were manufactured post-1839, and consequently led to relating the shipwreck to the 1840 naval bombardment of Akko (Mentovich et al., 2010). In addition, historical evidence points to the fact that on the eve of this battle, a merchant brig was observed anchoring in the harbour (Codrington, 1880).

To summarize, the metallurgical analysis of the two T-shaped anchors found in the Tantura F shipwreck has contributed significant information relating to their manufacturing process, and the analysis of the chemical composition of the two cannonballs from the Akko 1 shipwreck has provided a strong hint regarding their dating, and hence of the wrecking event. These two case studies present the valuable contribution made by archaeometallurgical investigations for the study of shipwreck and their artifacts.

\section{Acknowledgments}

The underwater excavations and research of the Akko 1 shipwreck have been supported by Mr. Ron Marlar, the Yaacov Salomon Foundation, the Halpern Foundation, the Sir Maurice Hatter Fellowship, Hecht Trust, the Jewish National Fund Fellowship, anonymous donors, the late Mr. Reuven Sadnai-Coral Maritime Services Ltd., and the President, Rector, Dean and Faculty of Humanities, University of Haifa. The underwater excavations and research of the Tantura F shipwreck was supported by Lord Jacobs of London, the Israel Science Foundation, the Hecht Trust, the Sir Maurice Hatter Fellowship, and the University of Haifa. The authors are grateful to them all.

Further thanks are due to Prof. Yuval Goren, Department of Archaeology and Ancient Near Eastern Civilizations, Tel Aviv University; and to Mario Levinstein, David Schreiber and Moshe Eliyahu from the School of Mechanical Engineering at Tel Aviv University for their assistance. The authors would also like to thank Dr. Zahava Barkai of the Wolfson Applied Materials Research Centre at Tel Aviv University for her assistance.

\section{References}

Aliya, D. \& Lampman, S. (2004). Physical Metallurgy Concepts in Interpretation of Microstructures, Metallography and Microstructures, In Vander Voort, G.F. (Editor) ASM Metals Handbook Vol. 9: Metallography and Microstructures, ASM International, Ohio, 44-70.

Ashkenazi, D., Cvikel, D., Iddan, N., Mentovich, E.D., Kahanov, Y. \& Levinstain, M. (2011). Archaeometallurgical Study of the Brass Cases from the Akko 1 Shipwreck. Journal of Archaeological Sciences 38 (9), 2410-2419.

Balasubramaniam, R., Ramesh Kumar, A.V. \& Dillmann, P. (2003). Characterization of rust on ancient Indian iron. Current Science 85 (11), 1546-1555.

Balos, S., Benscoter, A. \& Pense, A. (2008). Roman mystery iron blades from Serbia. Materials Characterization 60, 271-276. 
Barkai, O. \& Kahanov, Y. (2007). The Tantura F shipwreck, Israel. International Journal of Nautical Archaeology 36 (1), 21-31.

Barkai, O., Kahanov, Y. \& Avissar, M. (2010). The Tantura F shipwreck-The ceramic material. Levant 42 (1), 88-101.

Barrena, M.I., Go'mez de Salazar, J.M. \& Soria, A. (2008). Roman iron axes manufacturing technology, Nuclear Instruments and Methods in Physics Research Section B: Beam Interactions with Materials and Atoms 266 (6), 955-960.

Blyth, P.H. \& Atkins, A.G. (2002). Stabbing of metal sheets by a triangular knife - An archaeological investigation. International Journal of Impact Engineering 27, 459473.

Callister, W.D. (2000). Fundamentals of Materials Science and Engineering. 5th edition, John Wiley and Sons, New York.

Caporaso, A.L., Carlson-Drexler C.G. \& Masters, J. (2008). Metallurgical analysis of shell and case shot artillery from the civil war battles of Pea Ridge and Wilson's Creek. Technical Briefs in Historical Archaeology 3, 15-24.

Codrington, H.J. (1880). Selections from the Letters (Private and Professional) of Sir Henry Codrington Admiral of the Fleet, Edited by his sister Lady Bourchier. Spottiswoode and Co., London.

Cornell, R.M. \& Schwertmann, U. (2003). The Iron Oxides: Structure, Properties, Reactions Occurrences and Uses, Wiley-VCH Press. NJ.

Cvikel, D. \& Kahanov, Y. (2009). The Akko 1 shipwreck, Israel: the first two seasons. The International Journal of Nautical Archaeology 38 (1), 38-57.

Eliyahu, E., Barkai, O., Goren, Y., Eliaz, N., Kahanov, Y. \& Ashkenazi, D. (2011). Metallurgy Analyzes of Ancient Iron Anchor from Tantura $F$ shipwreck. Journal of Archaeological Science 38 (2), 233-245.

Fontana, M.G. (1987). Corrosion Engineering. 3rd ed. McGraw-Hill, New York.

Goodway, M. (1998). History of casting, In Frissell H.J. (Editor) ASM Metals Handbook Vol. 15: Casting, ASM International, Ohio, 12-54.

Hošek, J. \& Košta, J. (2006). Metallography of the 9th century sword of a great Moravian nobleman buried in Mikulice (grave no. 580). Association of Metallurgical Engineers in Serbia. AME, Metallugija - Journal of Metallurgy, Broj 2-3 (12), 199_ 206.

Kahanov, Y. (1997). Wood conservation of the Ma'agan Mikhael Shipwreck. International Journal of Nautical Archaeology 26 (4), 316-329.

Kahanov, Y., Doherty, C. \& Shalev, S. (1999). The metal nails from the Ma'agan Mikhael ship. The International Journal of Nautical Archaeology 28 (3), 277-288.

Mapelli, C., Nicodemi, W. \& Riva, R.F. (2007). Microstructural investigation of a medieval sword produced in 12th Century AD. ISIJ International 47 (7), 1050-1057.

Menon, R. \& McKay, T. (1996). Welding of cast irons and steels, In Frissell HJ (Editor) ASM Metals Handbook Vol. 15: Casting, ASM International, Ohio, 1136-1140.

Mentovich, E.D., Schreiber, D.S., Goren, Y., Kahanov, Y., Goren, H., Cvikel, D. \& Ashkenazi, D. (2010). New insights regarding the Akko 1 shipwreck: a metallurgic and petrographic investigation of the cannonballs. Journal of Archaeological Science 37 (10), 2520-2528.

Murray, W.M. \& Cliff, C.B. (1993). ASM Handbook, Vol. 6: Welding, Brazing, and Soldering, 2nd Edition, ASM International, Ohio, 156-159. 
Najjaran, H., Sadiq R. \& Rajani, B. (2006). Fuzzy expert system to assess corrosion of cast/ductile iron pipes from backfill properties. Computer-Aided Civil and Infrastructure Engineering 21, 67-77.

Neff, D., Bellot-Gurlet, L., Dillmann, P. \& Bertholon, R. (2004). Structural characterization of corrosion products on archaeological iron: an integrated analytical approach to establish corrosion forms. Journal of Raman Spectroscopy 35 (8-9), 739-745.

Neff, D., Dillmann, P., Bellot-Gurlet, L. \& Beranger, G. (2005). Corrosion of iron archaeological artifacts in soil: characterization of the corrosion system. Corrosion Science 47, 515-535.

Neff, D., Bellot-Gurlet, L., Dillman, P., Solenn, R., \& Legrand, L. (2006a). Raman imaging of ancient rust scales on archaeological iron artifacts for long-term atmospheric corrosion mechanisms study. Journal of Raman Spectroscopy 37, 1228-1237.

Neff, D., Dillmann, P., Descostes, M. \& Beranger, G. (2006b). Corrosion of iron archaeological artifacts in soil: Estimation of the average corrosion rates involving analytical techniques and thermodynamic calculations. Corrosion Science 48, 29472970.

Nicodemi, W., Mapelli, C., Venturini, R. \& Riva, R. (2005). Metallurgical investigations on two sword blades of 7 th and 3rd Century BC found in Central Italy. ISIJ International 45 (9), 1358-1367.

North, N.A. (1976). Formation of coral concretions on marine iron. The International Journal of Nautical Archaeology and Underwater Exploration, 5 (3), 253-258.

Park J.-S., Gelegdorj, E. \& Chimiddorj, Y.-E. (2010). Technological traditions inferred from iron artefacts of the Xiongnu Empire in Mongolia. Journal of Archaeological Science 37 (11), 2689-2697.

Pense, A.W. (2000). Iron through the ages. Materials Characterization 45, 353-363.

Perttula, J. (2004). Wootz Damascus steel of ancient orient. Scandinavian Journal of Metallurgy 33, 92-97.

Pulak, C. (2004). The Padlocks. In Bass, G. F., Matthews, S. D., Steffy, J. R. and van Doorninck, F. H., Serçe Limant: An Eleventh-Century Shipwreck, I: The Ship and Its Anchorage, Crew, and Passengers. Texas A\&M University Press, College Station, 437452.

Stech, T. \& Maddin, R. (2004). Iron analysis. In: Bass, G.F. Matthews, S.D. Steffy J.R. and Van Doorninck, F.H., Serçe Limanı: An Eleventh-Century Shipwreck, I: The Ship and Its Anchorage, Crew, and Passengers. Texas A\&M University Press, College Station, 192-195.

Selwyn, L. (2004). Overview of archaeological iron: the corrosion problem, key factors affecting treatment, and gaps in current knowledge. Proceedings of Metal 2004 National Museum of Australia Canberra ACT (4-8 October), 294-306.

Stefanescu, D.M. (1996a). Thermodynamic Properties of Iron-Base Alloys, In Frissell HJ (Editor) ASM Metals Handbook Vol. 15: Casting, ASM International, Ohio, 118175.

Stefanescu, D.M. (1996b). Classification and basic metallurgy of cast iron, In Zwilsky KM (Editor) ASM Metals Handbook Vol. 1: Properties and selection: irons, steels, and high performance alloys, ASM International, Ohio, 17-201. 
Szurgot, M., Rożniakowski, K., Wojtatowicz, T.W. \& Polański, K. (2008). Investigation of microstructure and thermophysical properties of Morasko iron meteorites. Crystal Research and Technology 43 (9), 921-930.

Todorov, R.P. \& Khristov K.G. (2004). Structural transformations: Widmanstatten structure of carbon steels. Metal Science and Heat Treatment 46 (1-2), 49-53.

Tylecote, R.F. (1962). A history of metallurgy, 2nd Edition, The Metals Society, London, 4657.

Tylecote, R.F. \& Black, J.W.B. (1980). The effect of hydrogen reduction on the properties of ferrous materials. Studies in Conservation 25, 87-96.

Vander Voort, G.F. (2004). Metallography: An Introduction, In Vander Voort, G.F. (Editor) ASM Metals Handbook Vol. 9: Metallography and Microstructures, ASM International, Ohio, 3-20.

Van Doorninck, F.H. (2004). The anchors. In: Bass, G. F. Matthews, S. D. Steffy J.R. and Van Doorninck, F.H., Serçe Limanı: An Eleventh-Century Shipwreck, I: The Ship and Its Anchorage, Crew, and Passengers. Texas A\&M University Press, College Station, 189-233.

Wadsworth, J. \& Lesuer, D.R. (2000). Ancient and modern laminated composites - from the great Pyramid of Gizeh to Y2K*. Materials Characterization 45, 289-313.

Wayman, M.L. (2000). Archaeometallurgical contributions to a better understanding of the past. Materials Characterization 45, 259-267.

Wiltzen, T.S. \& Wayman, M.L. (1999). Steel files as chronological markers in North American fur trade sites. Archaeometry 41, 117-135. 


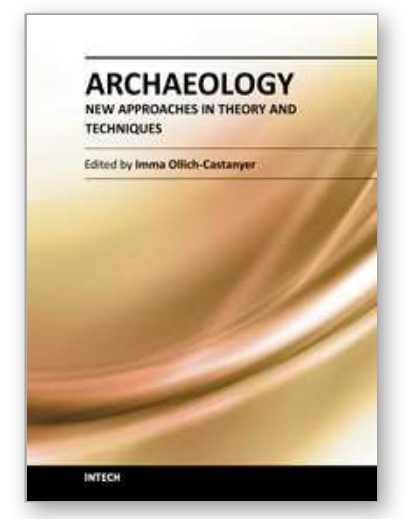

\author{
Archaeology, New Approaches in Theory and Techniques \\ Edited by Dr. Imma Ollich-Castanyer
}

ISBN 978-953-51-0590-9

Hard cover, 292 pages

Publisher InTech

Published online 09, May, 2012

Published in print edition May, 2012

The contents of this book show the implementation of new methodologies applied to archaeological sites. Chapters have been grouped in four sections: New Approaches About Archaeological Theory and Methodology; The Use of Geophysics on Archaeological Fieldwork; New Applied Techniques - Improving Material Culture and Experimentation; and Sharing Knowledge - Some Proposals Concerning Heritage and Education. Many different research projects, many different scientists and authors from different countries, many different historical times and periods, but only one objective: working together to increase our knowledge of ancient populations through archaeological work. The proposal of this book is to diffuse new methods and techniques developed by scientists to be used in archaeological works. That is the reason why we have thought that a publication on line is the best way of using new technology for sharing knowledge everywhere. Discovering, sharing knowledge, asking questions about our remote past and origins, are in the basis of humanity, and also are in the basis of archaeology as a science.

\title{
How to reference
}

In order to correctly reference this scholarly work, feel free to copy and paste the following:

D. Ashkenazi, E. Mentovich, D. Cvikel, O. Barkai, A. Aronson and Y. Kahanov (2012). Archaeometallurgical Investigation of Iron Artifacts from Shipwrecks - A Review, Archaeology, New Approaches in Theory and Techniques, Dr. Imma Ollich-Castanyer (Ed.), ISBN: 978-953-51-0590-9, InTech, Available from: http://www.intechopen.com/books/archaeology-new-approaches-in-theory-andtechniques/archaeometallurgical-investigation-of-iron-artifacts-from-shipwrecks-a-review

\section{INTECH}

open science | open minds

\section{InTech Europe}

University Campus STeP Ri

Slavka Krautzeka 83/A

51000 Rijeka, Croatia

Phone: +385 (51) 770447

Fax: +385 (51) 686166

www.intechopen.com

\section{InTech China}

Unit 405, Office Block, Hotel Equatorial Shanghai

No.65, Yan An Road (West), Shanghai, 200040, China 中国上海市延安西路65号上海国际贵都大饭店办公楼 405 单元

Phone: +86-21-62489820

Fax: $+86-21-62489821$ 
(C) 2012 The Author(s). Licensee IntechOpen. This is an open access article distributed under the terms of the Creative Commons Attribution 3.0 License, which permits unrestricted use, distribution, and reproduction in any medium, provided the original work is properly cited. 